\title{
Rhodobacter capsulatus puc operon: promoter location, transcript sizes and effects of deletions on photosynthetic growth
}

\author{
Heidi N. LeBlanc ${ }^{1}$ and J. Thomas Beatty ${ }^{1,2 *}$ \\ Departments of Microbiology ${ }^{1}$ and Medical Genetics ${ }^{2}$, University of British Columbia, Vancouver, BC, \\ Canada V6T $1 Z 3$
}

(Received 9 June 1992; revised 21 September 1992; accepted 28 September 1992)

\begin{abstract}
Gene deletions of the puc operon of Rhodobacter capsulatus showed that the pucC and pucE genes, but not pucD, were required for formation of wild-type levels of the LHII complex. Deletion of pucC or pucE also impaired photosynthetic growth. The effects of pucC deletion were suppressed by secondary mutations that mapped outside the puc operon. Fusion of a $l a c^{\prime} Z$ gene to $p u c E^{\prime}$ showed that most of $p u c E$ transcription originated from upstream of pucB. RNA blot analysis revealed a $2.4 \mathrm{~kb}$ transcript that hybridized to probes specific for the pucBA, pucC and $p u c D E$ regions, indicating that some puc operon messages extend from just before the pucB gene to just after the pucE gene.
\end{abstract}

\section{Introduction}

The integral membrane protein components of the photosynthetic apparatus of the bacterium Rhodobacter capsulatus include the reaction centre complex (the site of charge separation), and the two surrounding light harvesting complexes, light harvesting I (LHI; sometimes designated B870) and light harvesting II (LHII; B800-850) (reviewed by Kiley \& Kaplan, 1988; Drews, 1985). The two pigment-binding peptides of the LHII complex are encoded by the $p u c B A$ genes (Youvan \& Ismail, 1985). Two dicistronic RNA species of approximately $550 \mathrm{nt}$ in length encoding these genes have been characterized (Zucconi \& Beatty, 1988), and the puc operon was thought to consist of only these two genes. The $\mathrm{LHII}^{-}$mutant strain NK3 was then discovered to have a transposon inserted downstream of the pucBA genes, and three new open reading frames (ORFs) were discovered in this region by DNA sequencing (Tichy et al., 1989). The new ORFs were named the $p u c C$, pucD and pucE genes, since a transposon disruption of the $p u c C$ gene led to loss of the LHII complex, and the predicted protein sequence of the pucE gene matched the partial amino acid sequence of one of the two $14 \mathrm{kDa}$ proteins that co-purified with the LHII complex (Tichy et al., 1989). The organization of these genes is given in Fig. 1(a).

* Author for correspondence. Tel. (604) 822 6896; fax (604) 822 6041; email jtb@ubcmtsg.ca.
Because the transposon insertion mutation of the $p u c C$ gene in strain NK3 (Tichy et al., 1989, 1991) could be polar on the $p u c D$ and $p u c E$ genes, and interfere with their expression, it was not known whether one or more of the $p u c C$, pucD and $p u c E$ genes were required for formation of the LHII complex. Furthermore, although the $p u c C$ and $p u c E$ genes were reported to be required for normal levels of LHII complex (Tichy et al., 1991), the effects of puc gene deletions on growth has not been reported. It was also not known if all of the puc $C D E$ genes were transcribed from the $p u c B A$ promoter region, or whether there was a promoter located between the $p u c C$ and $p u c D E$ regions. However, a complementation analysis indicated that the pucC gene could not be expressed if the $p u c B A$ promoter region was not present (Tichy et al., 1989).

For these reasons, we investigated the requirements of the $p u c C, p u c D$ and $p u c E$ genes, individually, for cell growth and formation of the LHII complex. We created a mutant strain in which the chromosomal pucBACDE genes were replaced by an omega cartridge (Prentki \& Krisch, 1984), and complemented this deletion with plasmids carrying various combinations of puc operon genes. Plasmid-borne $p u c E^{\prime}:: l a c^{\prime} Z$ gene fusions were used to evaluate the location of the promoter(s) of the pucCDE genes. RNA species that hybridized to probes specific for the pucBA, pucC and pucDE regions, and were sufficiently long to encode the entire pucBACDE region, were detected in wild-type cells. 

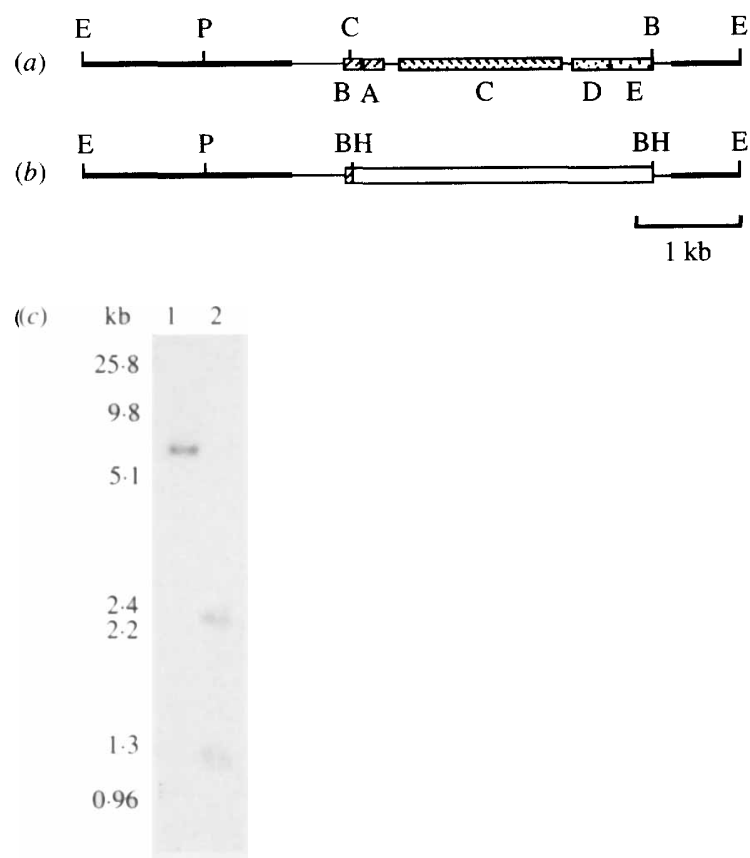

Fig. 1. Southern blot analysis of DNA from wild-type strain SB1003 and puc operon deletion/insertion strain $\Delta$ LHII. (a) Representation of the $5.5 \mathrm{~kb} E c o$ RI fragment that contains the puc operon. (b) Representation of the EcoRI fragment with the puc genes replaced by the omega cartridge. Hatched boxes designate puc genes, the open box the omega cartridge, and heavy lines unsequenced regions. Gene designations are given below the boxes, restriction enzyme sites above. Abbreviations of restriction sites: B, BcII; BH, BamHI; C, ClaI; E, EcoRI; P, PstI. (c) Results of Southern blot analysis. DNA from SB1003 (lane 1) and $\triangle$ LHII (lane 2) was doubly digested with EcoRI and $B a m \mathrm{HI}$, and probed with the $5.5 \mathrm{~kb} E c o \mathrm{RI}$ fragment.

\section{Methods}

Bacterial strains and growth conditions. All subcloning was done in the Escherichia coli strains JM83 (Yanisch-Perron et al., 1985), an hsdR derivative of C600 (Bibb \& Cohen, 1982), RB404 (Brent \& Ptashne, 1980 ) and SM 10 (Simon et al., 1983). Strain SM10 was used to transfer plasmids by conjugation to $R$. capsulatus (Simon et al., 1983). E. coli strains were grown at $30^{\circ} \mathrm{C}$ in Luria broth (Maniatis et al., 1982) supplemented with the appropriate antibiotics at the following concentrations: ampicillin, $200 \mu \mathrm{g} \mathrm{ml}^{-1}$, tetracycline- $\mathrm{HCl}, 10 \mu \mathrm{g} \mathrm{m}^{-1}$ and spectinomycin sulphate, $100 \mu \mathrm{g} \mathrm{ml}^{-1}$.

R. capsulatus strain SB1003 (Solioz \& Marrs, 1977) was used for RNA analysis, the promoter localization experiments and as the parent strain for construction of a pucBACDE deletion strain (see below). This $p u c$ operon deletion strain, $R$. capsulatus $\triangle$ LHII, was used for analyses of effects resulting from deletion of segments of the puc operon on LHII complex formation and in RNA blot analyses.

$R$. capsulatus strains were grown in RCV medium (Beatty \& Gest, 1981), sometimes supplemented with an appropriate antibiotic for plasmid maintenance, at $34^{\circ} \mathrm{C}$. Tetracycline- $\mathrm{HCl}$ and spectinomycin sulphate were used at concentrations of $0.5 \mu \mathrm{g} \mathrm{ml}^{-1}$ and $10 \mu \mathrm{g} \mathrm{ml}^{-1}$, respectively. High aeration growth conditions were defined as cultures grown in Erlenmeyer flasks filled to $8 \%$ of their nominal volumes and shaken at 300 r.p.m. in an orbital shaker. Low aeration growth conditions were obtained by filling flasks to $80 \%$ of their nominal capacities and shaking at 150 r.p.m. Stationary-phase low-oxygen cultures were used as inocula for photosynthetic cultures in screw cap tubes filled to capacity, and incubated with illumination provided by tungsten filament incandescent lamps with light intensities of either 30 or $300 \mu \mathrm{mol} \mathrm{m}^{-2} \mathrm{~s}^{-1}$. Light intensity was measured with a Li-Cor photometer equipped with an LI0190SB quantum sensor (Li-Cor, Lincoln Nebraska). Growth was monitored by measuring turbidity with a Klett-Summerson photometer (filter 66).

Construction of $R$. capsulatus strain $\Delta L H I I$. The $4.5 \mathrm{~kb}$ Pstl-EcoRI fragment bearing the pucBACDE genes (Fig. $1 a$ ) from pRPSLHII (Youvan \& Ismail, 1985) was first subcloned into pUC13 (YanischPerron et al., 1985) for ease of subsequent manipulations, yielding pHLB1. After digestion of pHLB1 with ClaI and partial digestion with $B c I$, the $4.6 \mathrm{~kb}$ vector fragment containing the sequences $3^{\prime}$ of the $B c l \mathrm{I}$ site at position 3030 of the published sequence (Tichy et al., 1989) and $5^{\prime}$ of the ClaI site in the puc operon (including the first 24 codons of the $p u c B$ gene) was purified, and treated with the Klenow fragment of DNA polymerase I to generate blunt ends (Maniatis et al., 1982). This fragment was recircularized, inserting a BamHI linker (5'-CCGGATCCGG-3') at the ligation site by linker tailing (Lathe et al., 1984). The omega fragment (Prentki \& Krisch, 1984) was then inserted into this BamHI site. The resultant $\triangle p u c B A C D E:: \Omega$ PstI-EcoRI fragment was inserted into the suicide vector pSUP202 (Simon et al., 1983) and introduced into SB1003 by conjugation. Spectinomycin resistant colonies were selected, and lighter coloured colonies were screened for loss of LHII by spectral analysis. Replacement of the puc operon as a result of a double cross-over event was confirmed by Southern blot analysis, as shown in Fig. 1 and described below.

DNA from SB 1003 and $\Delta$ LHII $(5 \mu \mathrm{g})$ was separately doubly digested with $E c o$ RI and $B a m \mathrm{HI}$, run on a $1 \%($ w/v) agarose gel and transferred to nitrocellulose paper (Maniatis et al., 1982). A non-radioactive DNA labelling kit (Boehringer Mannheim) was used to prepare digoxigeninlabelled probes from gel-purified DNA fragments. The blots were treated according to the kit's specifications until the development stage, when a fluorescent dye substrate for alkaline phosphatase (GibcoBRL) was used to develop the blots, after which they were exposed to $\mathrm{X}$-ray film (Kodak X-Omat) at room temperature for varying lengths of time before development.

As can be seen in Fig $1(c)$, a single band, corresponding to the $5.5 \mathrm{~kb}$ EcoRI fragment that hybridized to the puc operon probe, was obtained with SB1003 DNA. In contrast, $\triangle$ LHII DNA yielded two smaller bands, approximately 2.3 and $0.9 \mathrm{~kb}$ in size, which we interpret to represent fragments that consisted of the puc operon flanking sequences from the ends of the omega cartridge (delimited by the BamHI sites) to the $E c o$ RI sites.

Complementation plasmid constructions. The following deletions were made in the plasmid pHLB1 (see above) and transferred to the broad host-range plasmid pRK415 (Keen et al., 1988) as PstI-EcoRI fragments (Fig. 2). The omega fragment was inserted at the HindIII site upstream of the PstI site to reduce transcriptional read-through from plasmid promoters (Wellington et al., 1991). The positions of restriction enzyme sites given below refer to the numbering in the published DNA sequence (Tichy et al., 1989).

The pucCDE genes were deleted from the $B c l l$ site at position 1463 to the $B c l$ I site at 3030 , yielding plasmid $\mathrm{p} \triangle \mathrm{CDE}$. The deletion of the $p u c C$ gene extended from the $B c l I$ site at position 1463 to the $B s a B I$ site at 2217 , forming plasmid $\mathrm{p} \Delta \mathrm{C}$. Fusion of the filled-in $B c l$ site to the blunt $B s a \mathrm{BI}$ end created a translational stop codon.

A translationally in-frame deletion of $p u c D$ was created by filling in the $B c l$ I site at position 2348 and the Bss HI site at 2598 followed by religation $(\mathrm{p} \triangle \mathrm{D})$. The $p u c E$ deletion extends from the Eco47III site at 2761 to the $B c l l$ site at $3030(\mathrm{p} \Delta \mathrm{E})$. To ensure that translation beginning at the pucE start codon did not continue into the presumed transcription stop signal downstream of the deletion, an in-frame translational stop codon was created by adding a BamHI linker 


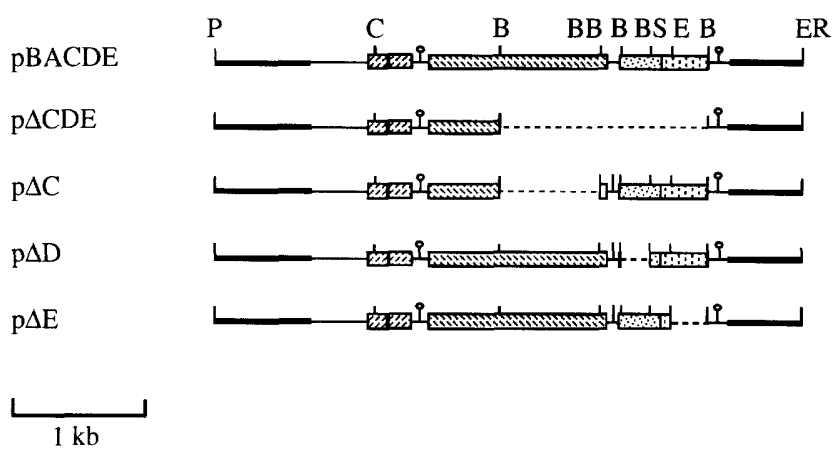

Fig. 2. Representations of the PstI-EcoRI plasmid inserts used to complement the $\Delta$ LHII deletion. Heavy lines designate unsequenced regions, $p u c$ operon structural genes are indicated as boxes, deletions shown by dashed lines, and potential mRNA stem-loop structures marked with loops. Abbreviations of restriction enzyme sites used in subcloning: B, BcII; BB, BsaBI; BS, BspHI; C, ClaI ; E, Eco47III; ER, EcoRI; P, PstI.

(5'-CGCGGATCCGCG-3') between the Eco47III and $B C I$ sites. The deletions of the $p u c D$ and $p u c E$ genes were confirmed by DNA sequencing (data not shown).

All experiments that used strain $\Delta$ LHII as a control in this communication were done with this strain containing the vector pRK415 carrying the omega fragment (pRK415:: $\Omega$ ).

To reconstitute the wild-type phenotype to strain $\triangle \mathrm{LHII}$, the $4.5 \mathrm{~kb}$ Pstl-EcoRI fragment that contained the $p u c B A C D E$ genes was subcloned into pRK415:: $\Omega$ to yield plasmid pBACDE.

Spectral analysis. Absorption spectra of about $1.8 \times 10^{9}$ intact cells, suspended in $1 \mathrm{ml} 22.5 \%(\mathrm{w} / \mathrm{v})$ BSA in RCV medium, were measured with a Hitachi U-2000 spectrophotometer, and data were collected with the Spectra Calc software package (Galactic Industries Corporation).

Construction of $p u c E^{\prime}:: l a c^{\prime} Z$ fusions and $\beta$-galactosidase assays. An in-frame fusion of the $p u c E^{\prime}$ to $\operatorname{lac}^{\prime} Z$ genes was obtained by cutting pHLB1 (see above) with BspHI and filling in the overhanging $5^{\prime}$ ends with the Klenow fragment of DNA polymerase I (Maniatis et al., 1982), followed by digestion with Pst I. The resultant $3.5 \mathrm{~kb}$ Pst I-bluntended fragment was then inserted into pUC13 digested with Pst $\mathrm{I}$ and $X b a \mathrm{I}$ (filled in with the Klenow enzyme), next to the BamHI site of pUC13, creating an in-frame fusion of the $\mathrm{pUC13}$ lac $Z$ allele to the fifth codon of pucE. A Pst I linker (5'-CCTGCAGG-3') was inserted at the $C l a \mathrm{I}$ site in the $p u c B$ gene, at the $B s a \mathrm{BI}$ site at the $3^{\prime}$ end of the pucC gene, or at the Hincll site in the pucD gene by linker tailing (Lathe et al., 1984), and the fragments shown in Fig. 5 were inserted into the promoter probe vector pXCA601 (Adams et al., 1989) as Pst $\mathrm{I}$-BamHI fragments.

The resultant plasmids were transferred to SB1003 by conjugation, and tetracycline-resistant recipients were purified. These cells were grown to a density of $90-100$ Klett units $\left(3.5-3.8 \times 10^{8}\right.$ c.f.u. $\left.\mathrm{ml}^{-1}\right)$ under high or low aeration conditions, harvested by centrifugation, resuspended and sonicated in $\beta$-galactosidase assay buffer (Miller, 1972) on ice. After centrifugation, the cleared supernatant liquids were assayed for $\beta$-galactosidase activity as described (Miller, 1972), except that $o$-nitrophenyl galactopyranoside (ONPG) cleavage was measured continuously in a spectrophotometer. Protein concentrations were determined by a modified Lowry procedure (Peterson, 1983).

RNA isolation, blot analysis and probe construction. RNA was isolated from $R$. capsulatus strains $\mathrm{SB} 1003$ and $\Delta$ LHII by the hot phenol method as described (von Gabain et al., 1983). Electrophoresis samples were ethanol-precipitated and denatured in a buffer containing formaldehyde and ethidium bromide (Rosen et al., 1990). RNA (5 $\mu \mathrm{g}$ per lane) was run on a $1.4 \%(\mathrm{w} / \mathrm{v})$ agarose/formaldehyde gel (Maniatis et al., 1982) beside $3 \mu \mathrm{g}$ per lane of a $0.24-9.5 \mathrm{~kb}$ RNA ladder (BRL). After electrophoresis the gel was equilibrated in $0.5 \times \mathrm{TBE}$ buffer (Maniatis et al., 1982), and photographed with UV illumination before electroblotting overnight at $30 \mathrm{~V}$ in $0.5 \times \mathrm{TBE}$ buffer onto a Biotrans nylon membrane (ICN). After blotting, the membrane was dried at $80^{\circ} \mathrm{C}$ under vacuum and exposed to UV light for comparison with the gel photograph to evaluate the efficiency of transfer.

Blotted membranes were prehybridized in $5 \times \operatorname{SSC}(1 \times \mathrm{SSC}$ is $0.15 \mathrm{M}$ $\mathrm{NaCl}, 0.015 \mathrm{M}$-sodium citrate), $1 \% \mathrm{SDS}, 10 \mathrm{~mm}$-EDTA and $50 \%(\mathrm{w} / \mathrm{v})$ formamide containing $0.5 \mathrm{mg} \mathrm{m}^{-1}$ denatured sheared salmon sperm DNA for $4-8 \mathrm{~h}$ at $42^{\circ} \mathrm{C}$ before addition of the denatured labelled probe. The blots were hybridized with the probes for $18 \mathrm{~h}$ at $42^{\circ} \mathrm{C}$.

DNA fragments for hybridization probes were purified by electroelution from $6 \%(\mathrm{w} / \mathrm{v})$ polyacrylamide gels run in $0.5 \times \mathrm{TBE}$ buffer (Maniatis et al. 1982). After phenol/chloroform (1:1) extraction and ethanol precipitation, the probes were labelled with $\left[\alpha-{ }^{32} \mathrm{P}\right] \mathrm{dATP}$ by the random primer method (Feinberg \& Vogelstein, 1983). Unincorporated nucleotides were removed using the Qiaex DNA purification procedure (Qiagen). The Qiaex eluate in TE buffer (Maniatis et al., 1982) was denatured at $90^{\circ} \mathrm{C}$ for $10 \mathrm{~min}$ and used directly for hybridization. The membranes were washed for $10-15$ min twice in $2 \times$ SSC, $1 \%$ SDS at room temperature, twice in the same solution at $50^{\circ} \mathrm{C}$ and for $5 \mathrm{~min}$ in $0 \cdot 2 \times$ SSC, $1 \%$ SDS at $50^{\circ} \mathrm{C}$. Blots were then exposed to Kodak XOmat film in a cassette with an intensifying screen at $-75^{\circ} \mathrm{C}$ for varying lengths of time before development.

\section{Results}

Effects of deletion of chromosomal pucBACDE genes
and complementation with segments of the puc operon
on LHII complex absorption spectra

Strain $\triangle$ LHII (Fig. $1 b$ ) was created by deletion of $2.5 \mathrm{~kb}$ from the $C l a \mathrm{I}$ site in the 25 th codon of $p u c B$ to the $B c / \mathrm{I}$ site in the termination codon of $p u c E$, and replacement with the omega fragment (see Methods). Strain $\triangle$ LHII(pRK415:: $\Omega$ ) lacked the LHII complex, as evidenced by the loss of absorption at 800 and $850 \mathrm{~nm}$ (Fig. $3 d$ ). Wildtype levels of LHII could be restored by complementation in trans with the plasmid pBACDE, which contained the entire puc operon (Figs 2 and $3 a$ ).

A series of plasmids was made that carried different deletions of the $p u c C, p u c D$ and $p u c E$ genes (Fig. 2), and these were conjugated into the $\Delta$ LHII strain. Spectral analysis of cells grown under conditions of low aeration showed that strains $\Delta \mathrm{LHII}(\mathrm{p} \Delta \mathrm{C})$ and $\Delta \mathrm{LHII}(\mathrm{p} \Delta \mathrm{CDE})$ had undetectable levels of LHII absorption (Figs $3 f$ and $3 e$, respectively). In contrast, strain $\Delta \mathrm{LHII}(\mathrm{p} \Delta \mathrm{E})$ showed about $64 \%$ of the level of LHII complex absorption (based on computer integration of the areas under the $800 \mathrm{~nm}$ peaks) found with $\triangle \mathrm{LHII}(\mathrm{pBACDE})$ (Fig. $3 c$ ), whereas the spectrum of $\Delta \mathrm{LHII}(\mathrm{p} \Delta \mathrm{D})$ showed no difference from the profile obtained with $\triangle$ LHII(pBACDE) (Fig. $3 b$ ). 


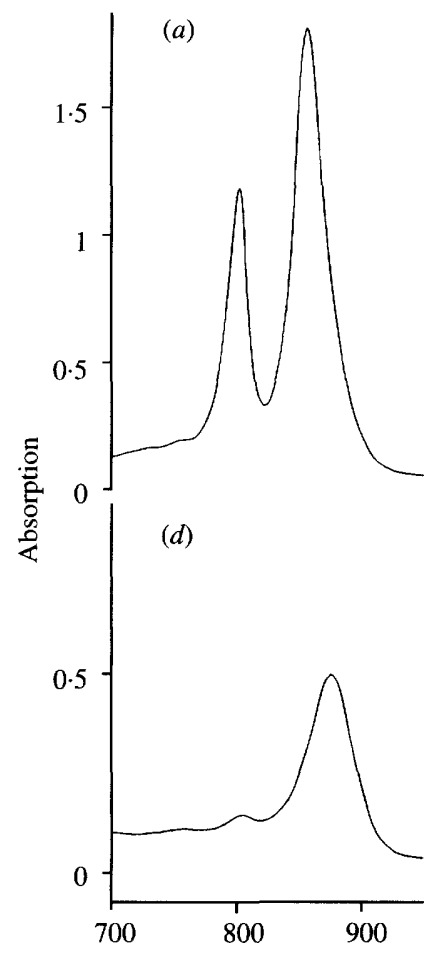

(b)



(c)



$(f)$

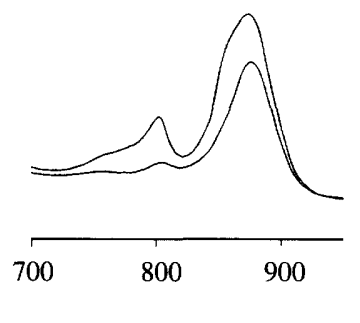

Fig. 3. Absorption spectra of intact cells grown under low aeration (see Methods). (a) $\Delta$ LHII(pBACDE), (b) $\Delta$ LHII(p $\Delta \mathrm{D}),(c)$ $\Delta \mathrm{LHII}(\mathrm{p} \Delta \mathrm{E}),(d) \Delta \mathrm{LHII}(\mathrm{pRK} 415:: \Omega),(e) \Delta \mathrm{LHII}(\mathrm{p} \Delta \mathrm{CDE})$ (lower trace), $\Delta$ LHII-2(p $\Delta \mathrm{CDE})$ secondary mutant (upper trace), $(f)$ $\Delta \mathrm{LHII}(\mathrm{p} \Delta \mathrm{C}$ ) (lower trace), $\Delta \mathrm{LHII}-1(\mathrm{p} \Delta \mathrm{C}$ ) secondary mutant (upper trace).

Growth characteristics of puc gene deletions and some properties of secondary mutant strains

Because the LHII complex is thought to increase the intracellular area of photon absorption and thus might aid photosynthetic growth at low light intensities (Drews, 1985), the puc gene deletion strains were tested for ability to grow photosynthetically at the low light intensity of $30 \mu \mathrm{mol} \mathrm{m}^{-2} \mathrm{~s}^{-1}$ (Fig. $4 a$ ). At this intensity of light, strain $\triangle$ LHII(pBACDE) was light-limited for growth, with a doubling time of $12 \mathrm{~h}$, whereas at saturating light intensities the doubling time was typically about $2 \mathrm{~h}$ (see below).

Surprisingly, strain $\Delta \mathrm{LHII}(\mathrm{pRK} 415:: \Omega)$ grew only slightly slower than $\triangle \mathrm{LHII}(\mathrm{pBACDE})$, despite undetectable levels of the LHII complex (Fig. 3d). The kinetics and extent of growth of $\Delta \mathrm{LHII}(\mathrm{p} \Delta \mathrm{D})$ at $30 \mu \mathrm{mol} \mathrm{m}^{-2} \mathrm{~s}^{-1}$ were indistinguishable from $\Delta$ LHII(pBACDE). Strain $\Delta \mathrm{LHII}(\mathrm{p} \Delta \mathrm{E})$, which had lower than normal levels of LHII (see Fig. 3c), had a much slower doubling time than strain $\triangle \mathrm{LHII}(\mathrm{pBACDE})$ and did not reach as great a density in stationary phase. Strain $\Delta \mathrm{LHII}(\mathrm{p} \Delta \mathrm{E})$ was tested for emission of fluorescence (Zilsel et al., 1989) to evaluate whether the LHII complex present might function improperly, but the fluorescence detected was similar to that of $\triangle \mathrm{LHII}(\mathrm{pBACDE})$ or $\Delta \mathrm{LHII}(\mathrm{p} \Delta \mathrm{D})$ (not shown).

The growth of strains $\Delta$ LHII $(\mathrm{p} \Delta \mathrm{CDE})$ and $\Delta$ LHII$(\mathrm{p} \Delta \mathrm{C})$ was the most impaired of those tested (Fig. $4 a$ ). Occasionally, faster-growing secondary mutants arose, distinguished by a marked increase in the slope of the growth curve and, in the case of $\Delta \operatorname{LHII}(\mathrm{p} \Delta \mathrm{C})$, by an unusual greenish colour. Aerobically-incubated plates streaked from faster growing $\Delta \mathrm{LHII}(\mathrm{p} \Delta \mathrm{CDE})$ and $\Delta$ LHII $(\mathrm{p} \Delta \mathrm{C})$ photosynthetic cultures showed two colony types: pink colonies similar to the original $\Delta$ LHII$(\mathrm{p} \Delta \mathrm{CDE})$ or $\Delta \mathrm{LHII}(\mathrm{p} \Delta \mathrm{C})$ strains, and darker red colonies. Spectra of pure cultures started from these dark pigmented colonies [designated $\Delta$ LHII-1 $(\mathrm{p} \Delta \mathrm{C})$ and $\Delta$ LHII-2(p $\Delta \mathrm{CDE})]$ showed that the cells had regained LHII complex absorption, but to different extents (Fig. $3 e$ and $f$ ). Strain $\Delta \mathrm{LHII}-2(\mathrm{p} \Delta \mathrm{CDE})$ had approximately wild-type levels of LHII complexes whereas $\Delta$ LHII$1(\mathrm{p} \Delta \mathrm{C})$ had much lower amounts of the LHII complex. These secondary mutant strains grew photosynthetically under light intensities of $30 \mu \mathrm{mol} \mathrm{m}^{-2} \mathrm{~s}^{-1}$ and 300 $\mu \mathrm{mol} \mathrm{m} \mathrm{m}^{-2} \mathrm{~s}^{-1}$ at rates similar to that of strain $\Delta$ LHII(pBACDE) (not shown). The appearance of secondary mutants was not observed in cultures of any of the other strains described here, or in $\Delta \mathrm{LHII}(\mathrm{p} \Delta \mathrm{C})$ or $\Delta \mathrm{LHII}-$ 

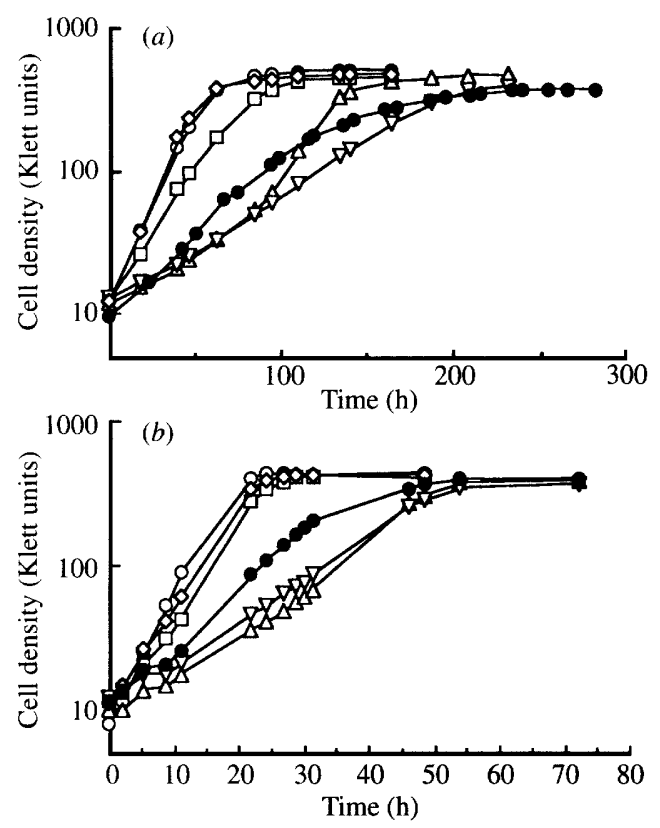

Fig. 4. Photosynthetic growth of cells with illumination at (a) $30 \mu \mathrm{m} \mathrm{m}^{-2} \mathrm{~s}^{-1}$ and (b) $300 \mu \mathrm{mol} \mathrm{m} \mathrm{m}^{-2} \mathrm{~s}^{-1}$. Strains: $\mathrm{O}, \Delta \mathrm{LHII}-$


$\Delta \mathrm{LHII}(\mathrm{p} \Delta \mathrm{C}) ; \diamond, \Delta \mathrm{LHII}(\mathrm{p} \Delta \mathrm{D}) ; \boldsymbol{\ominus}, \Delta \mathrm{LHII}(\mathrm{p} \Delta \mathrm{E})$. The growth of $\Delta \mathrm{LHII}(\mathrm{p} \Delta \mathrm{CDE})$ at low light intensity $(a)$ shows the appearance of a secondary mutant at approx. $80 \mathrm{~h}$. In experiments where none arose the growth curve was identical to that of $\Delta \operatorname{LHII}(\mathrm{p} \Delta \mathrm{C})$ (not shown).

( $\mathrm{p} \Delta \mathrm{CDE})$ cultures grown aerobically or photosynthetically with a light intensity of $300 \mu \mathrm{mol} \mathrm{m}^{-2} \mathrm{~s}^{-1}$.

Because the $\Delta \operatorname{LHII}(\mathrm{p} \Delta \mathrm{C}), \Delta \operatorname{LHII}(\mathrm{p} \Delta \mathrm{CDE})$ and $\Delta \mathrm{LHII}(\mathrm{p} \Delta \mathrm{E})$ strains grew more slowly than $\Delta$ LHII(pRK415:: $\Omega$ ) at a low light intensity, we grew the strains photosynthetically at $300 \mu \mathrm{mol} \mathrm{m}^{-2} \mathrm{~s}^{-1}$ to determine if they were also impaired in photosynthetic growth at high light intensity. Strains $\Delta$ LHII(pBACDE), $\Delta$ LHII $(\mathrm{p} \Delta \mathrm{D})$ and $\Delta$ LHII(pRK415:: $\Omega$ ) grew equally well with a doubling time of about $2 \mathrm{~h}$ (Fig. $4 b$ ). Strain $\Delta \mathrm{LHII}(\mathrm{p} \Delta \mathrm{E})$ grew more slowly with a doubling time of approx. $7 \mathrm{~h}$, whereas strains $\Delta \mathrm{LHII}(\mathrm{p} \Delta \mathrm{C})$ and $\Delta \mathrm{LHII}(\mathrm{p} \Delta \mathrm{CDE})$ grew very poorly, with about $10 \mathrm{~h}$ doubling times.

\section{pucE gene promoter location by deletion analysis of pucE'::lac'Z gene fusions}

Although previous work had shown that the $p u c C$ gene is probably transcribed from the $p u c B A$ promoter (Tichy et al., 1989, 1991), it was not clear where transcription of the $p u c D E$ genes originates. Therefore, to test for the positions of other possible puc operon promoters, inframe fusions of the $p u c E$ gene were made to the $E$. coli lac'Z gene (Fig. 5) in the promoter-probe plasmid pXCA601 (Adams et al., 1989). The specific activities of $\beta$-galactosidase were measured in cell extracts of $R$. capsulatus strain $\mathrm{SB} 1003$ containing the different $p u c E^{\prime}:: l a c^{\prime} Z$ fusions, grown under either high or low aeration (see Methods). Fig. 5 shows that approximately $90 \%$ of the expression of the $p u c E^{\prime}:: l a c^{\prime} Z$ fusion under low aeration derives from transcription initiated upstream of $p u c B$. The remaining $10 \%$ of $\beta$-galactosidase activity was lost when the region between the $3^{\prime}$ end of the pucC gene and the $5^{\prime}$ end of the pucD gene was deleted.

Comparison of $\beta$-galactosidase specific activities between SB1003(pPEZ) cells grown under high and low aeration shows that expression of this $p u c E^{\prime}:: l a c^{\prime} Z$ fusion averaged 1.8 -fold higher in cultures that were oxygen-starved. This is in good agreement with the

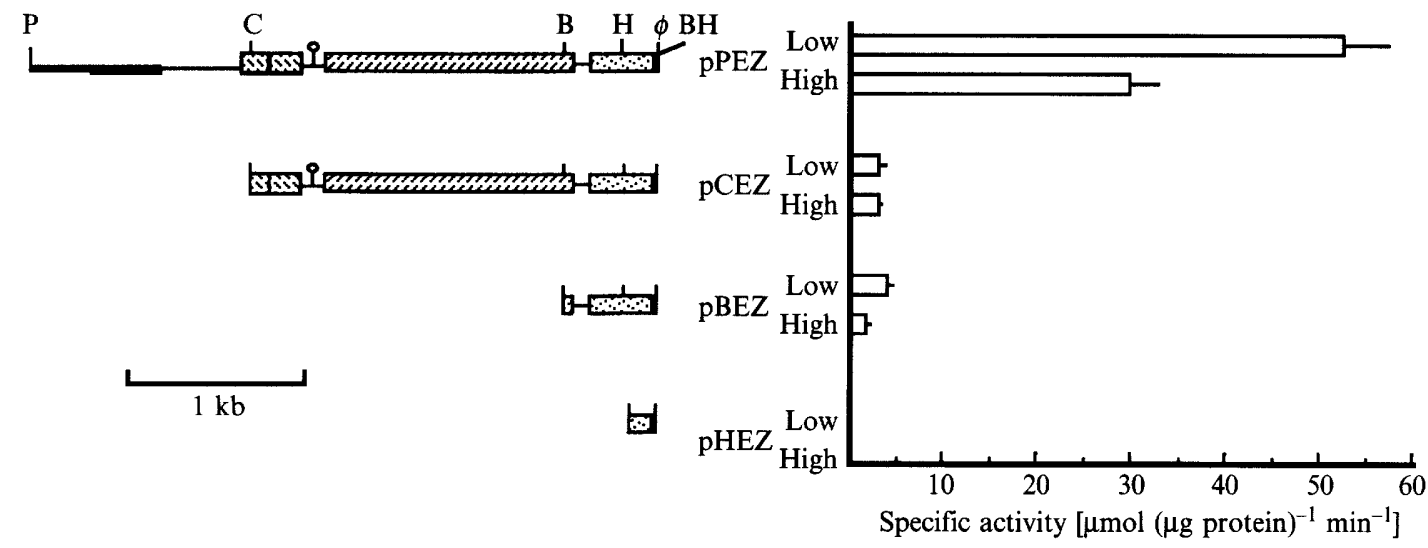

Fig. 5. Specific activities of $\beta$-galactosidase in cell extracts from wild-type $R$. capsulatus strain SB1003 containing plasmids with a $p u c E^{\prime}:: l a c^{\prime} Z$ fusion preceded by different amounts of upstream sequences, as shown. For example, pPEZ contains the entire upstream portion of the operon, whereas pHEZ contains only a segment of the $p u c D$ gene. 'High' and 'Low' refer to the degrees of aeration under which the cells were grown (see Methods). Specific activities expressed as $\mu \mathrm{mol}$ ONPG cleaved ( $\mu \mathrm{g}$ protein $)^{-1} \mathrm{~min}^{-1}$. Values are means of 3 assays and bars indicate standard deviations. Abbreviations for restriction enzyme sites used in cloning: P, PstI; C, ClaI; B, BsaBI; H, HinclI; $\varnothing, B s p H I / X b a I$ (both ends filled); $\mathrm{BH}$, BamHI. Other symbols are as in Fig. 2. 
(a)
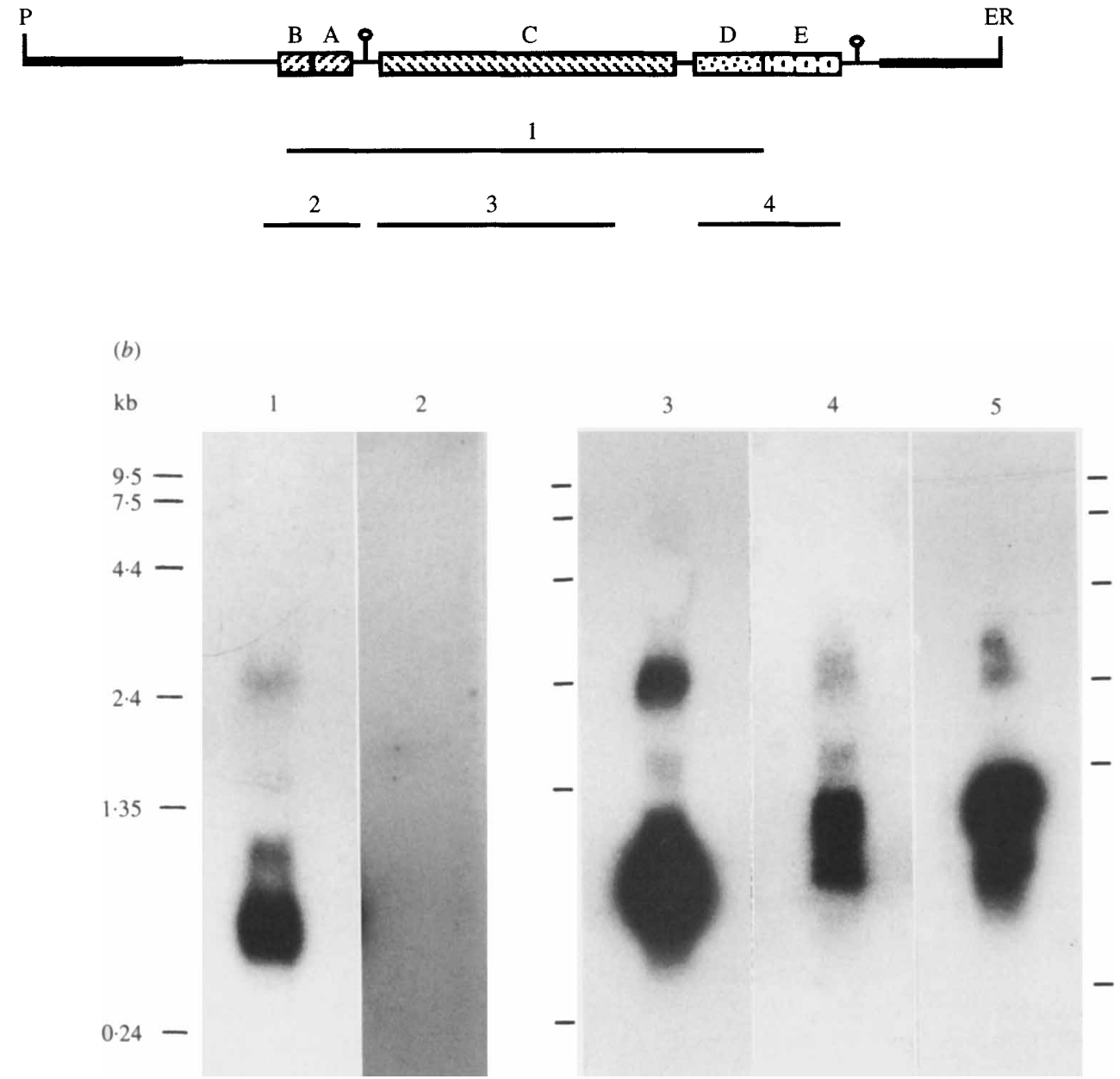

Fig. 6. RNA blot analysis of puc operon transcripts. (a) DNA probes used. Symbols and abbreviations as in Fig. 2. (b) Autoradiograms of hybridized blots of RNA isolated from SB1003 (lanes 1, 3-5) and $\triangle$ LHII (lane 2) cells grown under low aeration (see Methods). Lanes 1 and 2 were probed with the $2.2 \mathrm{~kb} \mathrm{ClaI} \mathrm{BspHI} \mathrm{fragment} \mathrm{(probe} \mathrm{1),} \mathrm{which} \mathrm{contains} \mathrm{the} \mathrm{pucBACDE} \mathrm{genes;} \mathrm{lane} 3$ with the $435 \mathrm{nt}$ BanII fragment (pucBA, probe 2); lane 4 with the $1 \cdot 1 \mathrm{~kb}$ BanII fragment (pucC, probe 3); and lane 5 with the $635 \mathrm{nt} B c /$ fragment ( $p u c D E$, probe 4). Approximate positions of RNA size markers $(\mathrm{kb})$ are indicated beside the blots.

results obtained using a $p u c B^{\prime}:: l a c^{\prime} Z$ fusion in cells grown under the same conditions (Forrest et al., 1989).

\section{$R N A$ blot analysis of the puc region shows several RNA species}

Because $p u c E^{\prime}:: l a c^{\prime} Z$ fusions showed that most, if not all, of transcription of the $p u c E$ gene originated upstream of the $p u c B$ gene, RNA blot analyses were performed to determine whether RNA species long enough to encode all five of the $p u c$ genes could be detected in addition to the approx. $550 \mathrm{nt}$ pucBA messages previously characterized (Zucconi \& Beatty, 1988). When RNA from the wild-type strain SB1003 was probed with a $2 \cdot 2 \mathrm{~kb}$ fragment extending from the $C l a \mathrm{I}$ site in $p u c B$ to the $B s p \mathrm{HI}$ site in pucE (probe 1 in Fig. $6 a$ ), a $0.5 \mathrm{~kb}$ message was detected along with two other less abundant species (Fig. $6 b$, lane 1). These two weaker signals corresponded to sizes of $2.4 \mathrm{~kb}$ and $1.0 \mathrm{~kb}$. (The faint bands of approx. $1.5 \mathrm{~kb}$ visible in lanes 1,2 and 3 are artifacts caused by rRNA bands above and below this position that interfere with hybridization.) By scanning the autoradiogram on a densitometer, the relative amounts of the 0.5 $\mathrm{kb}: 1 \cdot 0 \mathrm{~kb}: 2 \cdot 4 \mathrm{~kb}$ species were estimated as $35: 3: 1$.

The $2.4 \mathrm{~kb}$ species described above was large enough to encode all five puc genes. In order to evaluate whether 
it might, and to identify the sequences present in the smaller species, further RNA blot analyses were carried out using probes specific for smaller segments of the $p u c$ region (Fig. 6a). A probe specific for the $p u c B A$ genes detected only the largest $(2.4 \mathrm{~kb})$ and smallest $(0.5 \mathrm{~kb})$ bands (Fig. 6b, lane 3). A probe specific for the pucDE region detected bands comigrating with the 1.0 and $2.4 \mathrm{~kb}$ species, as well as a previously undetected message of about $0.7 \mathrm{~kb}$ (Fig. $6 b$, lane 5). When a probe containing only the $p u c C$ region was used, a signal comigrating with the $1.0 \mathrm{~kb}$ band detected by the $p u c D E$ probe was detected, along with a fainter $2.4 \mathrm{~kb}$ signal (Fig. 6b, lane 4). A smear extending down from the $1.0 \mathrm{~kb}$ band ended approximately where the $0.5 \mathrm{~kb}$ signal was found with the $p u c B A$-containing probes. Although some signals are over-exposed in Fig. 6, to better show the faint bands, autoradiograms of shorter exposures of these and other blots clearly showed the presence and absence of the bands noted above.

When RNA from the $\triangle$ LHII strain was probed with the pucBACDE fragment no bands were detected (Fig. $6 b$, lane 2), indicating that none of the signals resulted from cross-hybridization to non-puc operon derived messages, as was reported with Rhodobacter sphaeroides (Lee et al., 1989).

\section{Discussion}

Effects of deletion of chromosomal pucBACDE genes and complementation with segments of the puc operon on LHII complex absorption spectra

This report describes the deletion of the entire puc$B A C D E$ region and demonstrates that all of the genes downstream of $p u c B A$ are transcribed primarily from a promoter upstream of $p u c B$. Previous studies of the expression of the pucCDE genes in $R$. capsulatus drew conclusions from studies of a mutant with a transposon inserted in the $p u c C$ gene (strain NK3), or a deletion of only the $p u c B, p u c A$ and part of the $p u c C$ genes (strain U72) (Tichy et al., 1989, 1991). The interpretations of these previous experiments were complicated by the likely polar effects of the transposon insertion and the possibility of a strong promoter located between the pucC and pucD genes. Therefore, it is not clear whether the $p u c D$ and $p u c E$ genes were expressed in the mutants NK3 or U72 (Tichy et al., 1991). In that report the authors suggested that deletion of the entire puc region was lethal, whereas we found that deletion of the entire $p u c B A C D E$ region was not lethal or generally deleterious to cell growth.

The deletion analysis described here shows that two of the three genes downstream of $p u c B A$ are required to obtain normal levels of the LHII complex. One of these genes, $p u c E$, encodes one of the $14 \mathrm{kDa}$ proteins that copurify with LHII complex $\alpha$ and $\beta$ pigment-binding proteins (Tichy et al., 1989), and its deletion impaired LHII complex formation. This $p u c E$ deletion strain synthesized less LHII complex than the wild-type (see Fig. $3 c$; in several experiments the values of the areas under the $800 \mathrm{~nm}$ peaks were approximately $65 \%$ of the wild-type controls for low-oxygen cultures, and about $37 \%$ for photosynthetically grown cultures), and the absorption of the $800 \mathrm{~nm}$ peak seemed to be disproportionately low relative to that at $850 \mathrm{~nm}$. This $800 \mathrm{~nm}$ absorption peak is probably associated with the periplasmic side of the complex (Fowler et al., 1992).

Deletion of the pucC gene leads to a complete loss of LHII complex absorption. Both of our puc $C$ and puc $E$ deletion results are consistent with the work of Tichy et al. (1991). In contrast, we found that deletion of the puc $D$ gene had no apparent effect on LHII complex levels detected by spectroscopy. This difference could be explained by a secondary effect on expression of puc $E$ if the pucD deletion used by Tichy et al. (1991) was not translationally in-frame, and translational coupling between the $p u c D$ and $p u c E$ genes was therefore lost (see below).

The appearance of secondary mutants that express LHII complexes in low-light-grown photosynthetic cultures of $\Delta \mathrm{LHII}(\mathrm{p} \Delta \mathrm{C})$ and $\Delta \mathrm{LHII}(\mathrm{p} \Delta \mathrm{CDE})$ implies that at least one other gene is capable of providing the function of the missing pucC gene, and presumably its own normal function, when modified due to a mutation. We have evidence that these mutations are chromosomally located in both $\Delta$ LHII- $1(\mathrm{p} \Delta \mathrm{C})$ and $\Delta$ LHII$2(\mathrm{p} \Delta \mathrm{CDE})$, since transfer of the plasmids from these strains to strain $\Delta$ LHII gave the same phenotypes as plasmids $\mathrm{p} \Delta \mathrm{C}$ and $\mathrm{p} \Delta \mathrm{CDE}$ (unpublished data). The data presented here do not distinguish whether the differences in absorption spectra of $\Delta \mathrm{LHII}-1(\mathrm{p} \Delta \mathrm{C})$ and $\Delta \mathrm{LHII}$ $2(\mathrm{p} \Delta \mathrm{CDE})$ are due to different suppressor mutations, or result from the presence or absence of the $p u c D E$ genes.

Two candidates as sites for a mutation that suppresses the effects of $p u c C$ gene deletion are ORF1696, found upstream of the puhA gene, and ORF428 [located between the bchG and bchJ genes; Burke et al., 1991, sequence obtained from GenBank (accession Z11165)]. The amino acid sequence of ORF 428 has $26 \%$ identity to PucC, but the function of this putative gene has not yet been evaluated. However, the predicted amino acid sequence of ORF 1696 has $47 \%$ identity to that of PucC (Bauer et al., 1991), and mutations in ORF1696 have been shown to decrease levels of the LHI complex by about $30 \%$ (Bauer et al., 1991). We therefore speculate that the function of ORF1696 in the assembly of LHI complexes is analogous to that of pucC in the assembly of LHII complexes, and that mutation of ORF 1696 
allows it to compensate for the deletion of $p u c C$. This hypothesis is under investigation.

\section{Growth characteristics of puc gene deletion strains}

A surprising result of the growth studies of the mutants described in this report was that deletion of the pucC or $p u c E$ genes had a more deleterious effect on photosynthetic growth than deletion of the entire puc operon (see Fig. 4). Compared to the photosynthetic growth of strain $\triangle$ LHII(pBACDE), the strain $\Delta$ LHII(pRK415:: $\Omega$ ) grew equally well at $300 \mu \mathrm{mol} \mathrm{m}^{-2} \mathrm{~s}^{-1}$ and only slightly more slowly at $30 \mu \mathrm{mol} \mathrm{m}^{-2} \mathrm{~s}^{-1}$. In contrast, strains $\Delta \mathrm{LHII}(\mathrm{p} \Delta \mathrm{C}), \Delta \mathrm{LHII}(\mathrm{p} \Delta \mathrm{CDE})$ and $\Delta \mathrm{LHII}(\mathrm{p} \Delta \mathrm{E})$ grew very poorly, even though the $\Delta \mathrm{LHII}(\mathrm{p} \Delta \mathrm{E})$ strain had about $37 \%$ of the wild-type levels of the LHII complex. It would thus appear that expression of the pucBA genes interferes with the photosynthetic growth capabilities of cells in the absence of the pucC or pucE genes. No growth significant differences were seen in aerobic dark rates (data not shown).

\section{puc operon promoter location by deletion analysis of} puc $E^{\prime}:: l a c^{\prime} Z$ gene fusions

Promoter activity was not detected between the $p u c A$ and pucC genes (Tichy et al., 1989), although transcription initiated at the nifHDK promoter could proceed through the inverted repeat sequence located between these two genes to allow expression of pucC (Tichy et al., 1991). However, it was not clear if the $p u c B A$ promoter (as opposed to the nifHDK promoter) could drive transcription of the pucCDE genes, or whether another promoter was present in the region downstream of the $p u c C$ gene. Our results, with a fusion between the $p u c E$ and $l a c Z$ genes, show that at least $90 \%$ of transcription of the $p u c E$ gene originates in the previously mapped pucBA promoter region (Fig. 5), and that this transcription has a similar degree of oxygen regulation to that of $p u c B^{\prime}-l a c^{\prime} Z$ fusions (Forrest et al., 1989). The remaining $10 \%$ of promoter activity associated with the region between the BsaBI site in the $3^{\prime}$ end of the pucC gene and the HincII site in the pucD gene could indicate the presence of a minor promoter in this region. Alternatively, the low level of transcription in the pCEZ and $\mathrm{pBEZ}$ constructs may be due to a low level of readthrough from a plasmid promoter. With either possibility, the decrease in activity between the pBEZ and the pHEZ constructs (Fig. 5) could represent a contribution of translational coupling of the $p u c D$ gene to expression of $p u c E$, since these genes overlap by four nucleotides (Tichy et al., 1989). That is, if these genes were translationally coupled, translation of the $p u c E$ message would decrease when the $5^{\prime}$ end of the $p u c D$ gene (including the ribosome binding site and start codon) was deleted. Although our results show that most of the expression of the $p u c E$ gene derives from transcription initiated at the $p u c B A$ promoter, the data do not preclude the possibility of a small contribution by a minor promoter between the pucC and pucD genes, translational coupling between the $p u c D$ and $p u c E$ genes, or some combination of these possibilities.

\section{$R N A$ blot analysis of the puc operon region shows multiple RNA species}

Localization of nearly all of the promoter activity for transcription of the $p u c E^{\prime}:: l a c^{\prime} Z$ fusion to the region upstream of $p u c B$ implied that it might be possible to detect an RNA species sufficiently long to encode all five puc genes. As shown in Fig. $6 b$, the $2.2 \mathrm{~kb} p u c B A C D E$ probe detected messages of approximately $0.5 \mathrm{~kb}, 1.0 \mathrm{~kb}$ and $2.4 \mathrm{~kb}$. The $0.5 \mathrm{~kb}$ signal was the most abundant and was detected by the $p u c B A$ probe, but not the pucC or pucDE probes, indicating that it represents the two previously characterized approx. $550 \mathrm{nt}$ pucBA mRNAs (Zucconi \& Beatty, 1988).

The $1.0 \mathrm{~kb}$ RNA species detected with the pucBACDE probe was approximately 10 -fold less abundant than the $p u c B A$ mRNA. A strong signal migrating to the same position was detected by a pucDE-specific probe, and a signal of the same size was also detected using a probe to the $p u c C$ region. These results could either be due to two similarly-sized species, or the $3^{\prime}$ end of the puc $C$ probe could overlap with the $5^{\prime}$ end of the RNA molecule detected by the $p u c D E$ probe. The distance from the $3^{\prime}$ end of the $p u c C$ probe to the presumed transcriptional terminator downstream of pucE (Tichy et al., 1989) is approximately $1.2 \mathrm{~kb}$, which is about the size of the RNA species detected by both probes. If these probes did hybridize with the same RNA molecule, this $1.0 \mathrm{~kb}$ species would be more likely to have been generated by processing of a primary transcript than by promoter activity, since none was detected in this region by the $p u c E^{\prime}:: l a c^{\prime} Z$ fusions (see above). The $p u c E^{\prime}:: l a c^{\prime} Z$ fusions indicated that there might be minor promoter activity in the region between the BsaBI site near the $3^{\prime}$ end of $p u c C$ and the $H i n c I I$ site within $p u c D$. Transcripts originating from this potential minor promoter and ending at the supposed transcriptional terminator downstream of pucE (Tichy et al., 1989) would be approximately $0.7 \mathrm{~kb}$, and a minor band of $0.7 \mathrm{~kb}$ was detected using the $p u c D E$ probe. This signal would not be visible using the larger $p u c B A C D E$ probe because it would be masked by the $0.5 \mathrm{~kb}$ signal.

All of the probes used detected signals of a RNA species migrating at about $2 \cdot 4 \mathrm{~kb}$. Combined with the results of the $p u c E^{\prime}:: l a c^{\prime} Z$ fusions, this strongly implies 
that transcripts encoding all five $p u c$ operon genes originate at the $p u c B A$ promoter. The presence of smaller species, especially the $1.0 \mathrm{~kb}$ species detected by the pucBACDE, pucC and pucDE probes, and the relatively low abundance of the $2.4 \mathrm{~kb}$ message, imply that a $2.4 \mathrm{~kb}$ primary transcript is degraded to generate more stable products. It remains to be seen if the $3^{\prime}$ end of the $0.5 \mathrm{~kb}$ pucBA mRNAs corresponding to the inverted repeat between puc $A$ and puc $C$ are created by processing, as has been shown for the puf operon (Chen et al., 1988), or are due to attenuation of transcription in this region.

Analysis of puc RNA in the related species $R$. sphaeroides demonstrated the presence of a $2.3 \mathrm{~kb}$ message having the same $5^{\prime}$ end as a more abundant $0.5 \mathrm{~kb}$ pucB $A$ transcript (Lee et al., 1989). The authors concluded that this $2.3 \mathrm{~kb}$ molecule was required for formation of the LHII complex. It has not been reported whether or not $R$. sphaeroides contains pucCDE gene homologues. Although transcripts of the $p u c B A$ genes continue into the region downstream of $p u c A$ and this downstream region is associated with LHII complex formation in both $R$. sphaeroides and $R$. capsulatus, the specific functions of the pucC, pucD and pucE gene products in LHII complex formation remain to be determined.

\section{References}

Adams, C. W., Forrest, M. E., Cohen, S. N. \& Beatty, J. T. (1989). Structural and functional analysis of transcriptional control of the Rhodobacter capsulatus puf operon. Journal of Bacteriology 171, 473-482.

Bauer, C. E., Buggy, J. J., Yang, Z. \& Marrs, B. L. (1991). The superoperonal organization of genes for pigment biosynthesis and reaction center proteins is a conserved feature in Rhodobacter capsulatus: analysis of overlapping $b c h B$ and puhA transcripts. Molecular and General Genetics 228, 438-444.

BeATTY, J. T. \& GEST, H. (1981). Generation of succinyl-coenzyme A in photosynthetic bacteria. Archives of Microbiology 129, 335-340.

BibB, M. J. \& CoHEN, S. N. (1982). Gene expression in Streptomyces: construction and application of promoter-probe plasmid vectors in Streptomyces lividans. Molecular and General Genetics 187, 265-277.

Brent, R. \& Ptashne, M. (1980). The lexA gene product represses its own promoter. Proceedings of the National Academy of Sciences of the United States of America 77, 1932-1936.

Burke, D., Alberti, M., Stein, D. \& Hearst, J. (1991). Chlorophyll Fe proteins and other chlorophyll biosynthesis genes from Rhodobacter capsulatus to higher plants. Photochemistry and Photobiology, Supplement 53, 85S-86S.

Chen, C.-Y. A., Beatty, J. T., Cohen, S. N. \& Belasco, J. G. (1988). An intercistronic stem-loop structure functions as an mRNA decay terminator necessary but insufficient for puf mRNA stability. Cell 52, 609-619.

Drews, G. (1985). Structure and functional organization of lightharvesting complexes and photochemical reaction centers in membranes of phototrophic bacteria. Microbiological Reviews 49, 59-70.

FeinberG, A. P. \& Vogelstein, B. (1983). A technique for radiolabelling DNA restriction fragments to high specific activity. Analytical Biochemistry 132, 6-13.
Forrest, M. E., Zucconi, A. P. \& Beatty, J. T. (1989). The puf $Q$ gene product of Rhodobacter capsulatus is essential for formation of B800-850 light-harvesting complexes. Current Microbiolog! 19. 123-127.

Fowler, G. J. S., Visschers, R. W., Grief, G. G., van Grondelle, R. \& Hunter, C. N. (1992). Genetically modified photosynthetic antenna complexes with blueshifted absorption bands. Nature. London 355, 848-850.

von Gabain, A., Belasco, J. G., Schottel, J. L., Chang, A. C. Y. \& CoHEN, S. N. (1983). Decay of mRNA in Escherichia colli: investigation of the fate of specific segments of transcripts. Proceedings of the National Academy of Sciences of the United States of America 80, 653-657.

Keen, N. T., Tamaki, S., Kobayashi, D. \& Trollinger, D. (1988). Improved broad-host range plasmids for DNA cloning in Gramnegative bacteria. Gene 70, 191-197.

KILEY, P. J. \& KaPlan, S. (1988). Molecular genetics of photosynthetic membrane biosynthesis in Rhodobacter sphaeroides. Microbiological Reviews 52, 50-69.

Lathe, R., Kieny, M.-P., Skory, S. \& Lecoce, J. P. (1984). Linkertailing: unphosphorylated linker oligonucleotides for joining DNA termini. DNA 3, 173-182.

Lee, J. K., Kiley, P. J. \& Kaplan, S. (1989). Posttranscriptional control of puc operon expression of B800-850 light-harvesting complex formation in Rhodobacter sphaeroides. Journal of Bacteriology 171, 3391-3405.

Maniatis, T., Fritsch, E. F. \& Sambrook, J. (1982). Molecular Cloning: a Laboratory Manual. Cold Spring Harbor, NY: Cold Spring Harbor Laboratory Press.

MiLleR, J. H. (1972). Experiments in molecular genetics. Cold Spring Harbor, NY: Cold Spring Harbor Laboratory Press.

Peterson, G. (1983). Determination of total protein. Methods in Enzymology 91, 95-119.

PrentKI, P. \& Krisch, H. M. (1984). In vitro insertional mutagenesis with a selectable DNA fragment. Gene 29, 303-313.

Rosen, K. M., Lamperti, E. D. \& Villa-Komaroff, L. (1990). Optimizing the northern blot procedure. BioTechniques 8, 398-403.

Simon, R., Priefer, U. \& Pühler, A. (1983). A broad host range mobilization system for in vivo genetic engineering: transposon mutagenesis in Gram-negative bacteria. Bio/Technology 1, 37-45.

Solioz, M. \& MarRs, B. (1977). The gene transfer agent of Rhodopseudomonas capsulata. Archives of Biochemistry and Biophysics 181, 300-307.

Tichy, H. V., Oberlé, B., Stiehle, H., Schiltz, E. \& Drews, G. (1989). Genes downstream from $p u c B$ and $p u c A$ are essential for formation of the B800-850 complex of Rhodobacter capsulatus. Journal of Bacteriology 171, 4914 4922.

Tichy, H. V., Albien, K. U., Gad'on, N. \& Drews, G. (1991). Analysis of the Rhodobacter capsulatus puc operon - the pucC gene plays a central role in the regulation of LHII (B800-850 complex) expression. EMBO Journal 10, 2949-2955.

Wellington, C. L., Taggart, A. K. P. \& Beatty, J. T. (1991) Functional significance of overlapping transcripts of $\operatorname{crt} E F, b c h C A$, and puf photosynthesis gene operons in Rhodobacter capsulatus. Journal of Bacteriology 173, 473-482.

Yanisch-Perron, C., Vieira, J. \& Messing, J. (1985). Improved M13 phage cloning vectors and host strains: nucleotide sequences of M13 and pUC vectors. Gene 33, 103-119.

Youvan, D. C. \& Ismail, S. (1985). Light harvesting II (B800-850 complex) structural genes from Rhodopseudomonas capsulata. Proceedings of the National Academy of Sciences of the United States of America. 82, 58-62.

Zilsel, J., Lilburn, T. \& Beatty, J. T. (1989). Formation of functional interspecies hybrid photosynthetic complexes in Rhodobacter capsulatus. FEBS Letters 253, 247-252.

ZuCCONI, A. P. \& BeAtTy, J. T. (1988). Posttranscriptional regulation by light of the steady-state levels of mature B880-850 light-harvesting complexes in Rhodobacter capsulatus. Journal of Bacteriology 170. $877-882$. 